\title{
Are Central American export specialization patterns "sticky"?
}

\section{Klaus Lindegaard}

International Konkurrence Evne (IKE),

Department of Business Studies, Aalborg University,

Denmark

$k l @ i 4 . a u c . d k$

Leiner Vargas

International Centre

of Economic Policy

for Sustainable

Development (CINPE),

National University,

Costa Rica

lvargas@una.ac.cr
In the national innovation systems of the Organisation for

Economic Co-operation and Development (OECD), countries' export performance is considered to be the measure of their international competitiveness. The national specificity of economic performance is shown by the "stickiness" of each country's export pattern and indicates how much room for manoeuvre there is in each case for economic development policy initiatives. The authors introduce an analysis of the export specialization patterns of the Central American countries. They follow the methodology of innovative European research, taking into account econometric evidence of revealed symmetric comparative advantage for those countries' exports to the OECD, the CAN database of ECLAC being used for this purpose. This global analysis shows that in these countries' exports, agriculture- and maquila-based products with little value added have "sticky" characteristics. 


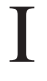

\section{Introduction}

The specialization pattern of an economy is a central aspect of the study of national systems of innovation (NSI). The dynamic and structure of the pattern are the base from which a particular country can learn and innovate. We can consider this pattern as a starting point for the understanding of the particular learning processes at work throughout the economic structure.

Recent debate and studies of the Organisation for Economic Co-operation and Development (OECD) countries have shown that specialization patterns display long-term stability (Dalum and Willumsen, 1996). This fits well with the argument of the institutional economic tradition that production patterns are characterized by path dependency and stickiness (Dosi, 1982). If a country follows its competitive advantages, trade specialization will reflect the existing pattern of production in one way or another. In addition, the dynamic that this pattern shows could be a good indicator for evaluating the hypothesis of stickiness and stability.

Following these arguments, and using the ECLAC trade database (ECLAC, 1995), the present paper applies an econometric model to the Balassa comparative advantage indicator. We follow the same methodology as applied by Dalum and Willumsen (1996) to turn the Balassa indicator of revealed comparative advantage (RCA) into a revealed symmetric comparative advantage (RSCA) indicator.

The most important finding described in this paper is the relative stability and stickiness of trade specialization patterns in the Central American countries. ${ }^{1}$ This stability and stickiness are the result

$\square$ A first draft of this text was presented at the Conference on National Innovation Systems (Rebild, Denmark, 1999) held by the Danish Research Unit for Industrial Dynamics (DRUID). The authors are grateful for the comments of participants in that session between DRUID and developing countries. of two simultaneous conditions. The first is the existence of path dependency resulting in lock-in development, in this case in sectors with low quality advantages for trade. The second is the political constraint resulting from trade agreement mechanisms and the resulting international pattern of trade between developed and developing countries. In developing countries, these two conditions have resulted in a specialization pattern based on low-skilled work and natural resource-intensive goods.

Using the national systems of innovation (NSI) approach, we argue in this paper that a new learning trajectory and the promotion of new industrial policies are crucial in the region in order to "lock out" from the existing trade pattern. The vicious circle of low-quality specialization, poverty and natural resource degradation needs to be broken if progress is to be made towards a more sustainable development process. To achieve this, the present paper argues for an innovation strategy of "learning by doing" and capitalizing on existing specializations.

Section II of this paper summarizes the theoretical discussion about competitiveness and innovation. Section III highlights the results of research into specialization patterns conducted recently in OECD countries. Section IV describes the main results and dilemmas of the competitiveness studies carried out in the Central American region. Section V presents a description of the Central American export structure. Section VI describes the econometric results of the stability test and analyses the stickiness of export specialization patterns in the Central American countries and the subregion as a whole. Lastly, section VII reviews the indicators and analyses the national system of innovation from the perspective of developing countries.

\footnotetext{
${ }^{1}$ See the Web page of the SUDESCA project (www.sudesca.una.ac.cr)
} for fuller treatment of these subjects. 


\section{II}

\section{Structural competitiveness and innovation}

The process of opening up national economies is leading to a focus on the trade balance and possible balance-of-payment constraints in the economic policy debate. The sustainability of that model depends on the scope for increasing the subregion's foreign direct investment and exports. A structural perspective on the issue points to problems related to the match between the domestic industrial structure and export markets, and to the point at which it is advisable to move from low-growth markets for traditional products to highgrowth markets for high-technology products.

Consideration of the trade and technological specialization patterns of the OECD countries reveals a mixed picture of convergence and divergence, as change is resulting in both broader and narrower specialization patterns. Patterns have proved relatively stable in most countries over time. Of course, they differ markedly from country to country and small countries tend to be more specialized than large countries (Dosi, Pavitt and Soete, 1990), while their trade specialization patterns are more diverse.

Mainstream economic tradition has put emphasis on static factors that affect the trade specialization pattern, such as natural resource endowments. Recently, new international trade theories have focused more on the creation of new advantages than on the exploitation of existing ones. The so-called "comparative advantage debate" has focused more on company-level aspects and static factors of sectoral analysis (Porter, 1991) than on the national or even sectoral level. More recently, the role of institutions and institutional change has been studied within the framework of national systems of innovation (Freeman, 1992; Lundvall, 1992; Edquist, 1997).
The NSI approach has shown that knowledge is an important factor for production and that learning is a crucial process. They are co-determinants of export performance and competitiveness in a particular country context. Of course, trade and interaction will be a source of new knowledge, but accumulation and path dependency effects mean that the knowledge base of an economy is closely related to its particular specialization pattern and industrial structure. Existing sectors are the base from which the learning process develops, for the most part incrementally through improvements to the existing basis of technological capabilities and institutional performance (Lundvall and Johnson, 1994).

If this line of reasoning is accepted, we should not expect Central American trade patterns to change dramatically within a few years. This is the first hypothesis, which is considered in this study. Another important aspect associated with this is the quality of the pattern. Small developing areas such as Central America cannot specialize in many activities, but the pattern followed has not hitherto created the conditions for sustainable long-term development. Are Central American trade patterns convergent or divergent in relation to the OECD countries? Are the OECD countries a benchmark to follow? What has been the recent evolution of the trade specialization pattern? All these questions, together with some considerations concerning the role of certain political constraints on trade and the room for manoeuvre left by trade agreements, are discussed in the following sections of this paper.

\section{III}

\section{OECD export specialization studies}

If competitiveness is understood as rising market share, particularly in growth markets (Dalum, 1992), then the trade specialization pattern must be viewed both as a reflection of an economy's learning and innovation activities and as the basis for planning competitiveness policies.

The work on structural competitiveness and national export specialization carried out by the IKE

ARE CENTRAL AMERICAN EXPORT SPECIALIZATION PATTERNS "STICKY"? - KLAUS LINDEGAARD AND LEINER VARGAS 
group in Aalborg makes use of the IKE Trade Database ${ }^{2}$ of OECD trade by commodities for the 21 "old" OECD countries (Belgium and Luxembourg taken together) with data from 1961 onward. Export market shares are given by country and industry, the latter being subdivided into: the five natural resource-based sectors; oil and natural gas; chemicals; engineering, electronics and transport equipment; other; and traditional industrial products. ${ }^{3}$

While a country's international competitiveness can be measured by its export performance (for example, by its export market share in an international market, like OECD), the revealed comparative advantage (RCA) index seeks to measure a country's relative export structure. This RCA indicator is equal to the percentage share of a given product in a country's exports, divided by the percentage share of that product in OECD exports. The RCA index compares national and OECD export structures, so that an RCA of 1 indicates an identical export structure, RCA above 1 indicates relative specialization, and RCA below 1 signifies despecialization in that product category (Dalum and Willumsen, 1996).

The above-mentioned study of convergence, divergence and stickiness in OECD trade specialization patterns tends to confirm the interpretation of the longterm history of market economies found in other studies, which show a series of shifting periods of either convergence or divergence.

Dalum and Willumsen (1996) used the IKE Trade Database on OECD trade by commodities. The RCA index was calculated for the period 1961-1992, which was later divided into two sub-periods (1961-1972 and 1973-1992) so that medium-term changes could be considered. Lastly, seven short periods (1961-1965, 1965-1969, 1969-1973, 1973-1979, 1979-1984, 19841988 and 1988-1992) were also analysed in order to study short-term development patterns.

\footnotetext{
${ }^{2}$ IKE (International Konkurrence Evne) group, international competitiveness project of the Department of Business Studies, Aalborg University, Denmark. The databases and the export specialization analysis indicators are further described in appendix A.

3 The data have been aggregated to 60 commodity groups in accordance with the Standard International Trade Classification (SITC), Revision 1. Stickiness measures could be affected by the level of aggregation. For example, if the dynamic of change is more intrasectoral in different products, greater aggregation will underestimate the real dynamism of the trade specialization pattern. However, disaggregation into too many products will produce an excessive number of zeros and provide few opportunities for comparative analysis.
}

The same study includes a statistical test for the stability of national export specialization patterns by looking at the development of the specialization index over time for the 21 countries. Using the framework of country regression models, the revealed symmetric comparative advantage (RSCA) indicator was tested as below: ${ }^{4}$

$$
R S C A_{i j}^{t 2}=\alpha_{i}+\beta_{i} R S C A_{i j}^{t 1}+\varepsilon_{i j}^{t 2}
$$

Here the dependent variable RSCA for country $i$ in the final year $t 2$ is tested against the independent variable in the initial year $t 1$ of the period.

If $\beta$ equals 1 , the specialization pattern is unchanged in the period. Conversely, $\beta$ above 1 signifies that the initial export specialization pattern of a country has been strengthened. This could be the result of an increase in the country's specialization in products it already specialized in and/or a decrease in its specialization in products it was already beginning to despecialize in. A $\beta$ value between 0 and 1 indicates that the country converged towards the OECD average during the period, so that exports of despecialized product categories grew above average and specialized product exports grew at a below-average rate.

The correlation coefficient $R$ gives a measure of the correlation between initial and final RSCA values. Therefore, it is a measure of the degree of change in the export ranking of the different products. A low $R$ value signifies great mobility in the distribution of the RSCAs, while $R$ equals 1 signifies no change in the product ranking during the period. A value below 0 indicates that the product ranking has changed fundamentally.

The variation coefficient of the country-wise regression models indicates, first, a regression effect. For example, a low $\beta$ value implies a high effect and a relatively strong tendency towards decline in initially advantaged industries and growth in initially disadvantaged ones. Second, it indicates a mobility effect: a low $R$ value implies a large effect and a high degree of structural change in the national economy. The two coefficients could be related to each other as the $\beta / R$ value, which gives an indication of the standard deviation (dispersion) of export specialization. A $\beta / R$ value above 1 signifies an increase in (the dispersion of) specialization, a value below 1 signifies a decrease in (the dispersion of) specialization, and a value equal to 1 signifies an unchanged specialization (Dalum and Willumsen, 1996).

\footnotetext{
${ }^{4}$ See appendix A.
}

ARE CENTRAL AMERICAN EXPORT SPECIALIZATION PATTERNS "STICKY"? • KLAUS LINDEGAARD AND LEINER VARGAS 
The main result of the country analysis was summarized as follows by the authors quoted. The less developed OECD countries generally show high regression effects (low $\beta$ ) and high mobility effects (low $R$ ), whereas most of the small high-income countries show low regression effects (high $\beta$ ) and low mobility effects (high $R$ ). The large countries usually show higher regression effects (lower $\beta$ values), implying a stronger tendency towards decrease in initially advantaged industries and increase in disadvantaged industries (Dalum and Willumsen, 1996, pp. 18-19).

The long-term period (1961-1992) shows a weak decrease in the dispersion of export specialization for all countries except Greece and Iceland, as indicated by the $\beta / R$ values ( 0.90 on average). Germany has a particularly low mobility effect, and Japan a particularly high one. In the medium-term periods (1961-1972 and 1973-1992) and the short-term ones, the analysis shows relatively high stability in export specialization patterns.

Dalum and Willumsen (1996) also looked at the bilateral similarity patterns of the OECD countries in the years 1961, 1973 and 1992 by analysing the pair-wise country correlations in the RSCAs. The stylized features of the bilateral comparison show a growing number of small countries tending (weakly) to achieve a specialization pattern similar to that of larger countries, while the same authors (ibid., p. 15) identify the following tendencies: i) small countries show similar specialization patterns to other small countries with a historically similar resource base; ii) large European countries resemble one another; iii) the United States and Japan are basically characterized by mutual dissimilarities, and iv) small countries typically show patterns different from those of large countries.

A more advanced econometric analysis of the material yielded similar conclusions concerning the relative stickiness of OECD export specialization patterns (Dalum, Laursen and Willumsen, 1996). Against this background, the authors cited conclude that these relatively stable export structures give an indication of national specificities for international competitiveness. Table 1 summarizes the results of this study for the OECD countries.

A general conclusion arrived at by the authors cited on the basis of this data is as follows. On the one side, the $\beta$ values are significantly different from zero and

TABLE 1

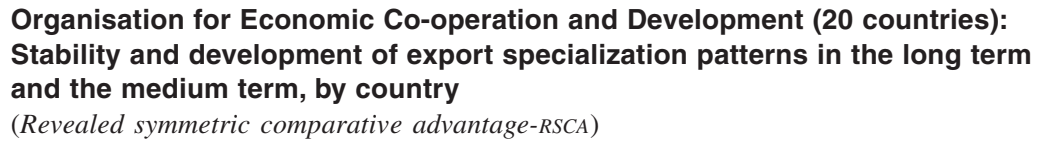

\begin{tabular}{|c|c|c|c|c|c|c|}
\hline \multirow[b]{2}{*}{ Country } & \multicolumn{3}{|c|}{$1965-1992$} & \multicolumn{3}{|c|}{ 1979-1992 } \\
\hline & $\beta$ & $R$ & $\beta / R$ & $\beta$ & $R$ & $\beta / R$ \\
\hline United States & 0.75 & 0.74 & 1.01 & 0.79 & 0.94 & 0.84 \\
\hline Japan & 0.62 & 0.58 & 1.07 & 0.95 & 0.93 & 1.03 \\
\hline Germany & 0.52 & 0.73 & 0.70 & 0.77 & 0.86 & 0.89 \\
\hline France & 0.37 & 0.40 & 0.94 & 0.78 & 0.78 & 1.00 \\
\hline Italy & 0.59 & 0.55 & 1.06 & 0.78 & 0.76 & 0.02 \\
\hline United Kingdom & 0.57 & 0.71 & 0.80 & 0.76 & 0.80 & 0.95 \\
\hline Belgium-Luxembourg & 0.66 & 0.69 & 0.96 & 0.97 & 0.91 & 1.07 \\
\hline Canada & 0.72 & 0.82 & 0.88 & 0.83 & 0.87 & 0.96 \\
\hline Denmark & 0.78 & 0.88 & 0.88 & 0.86 & 0.91 & 0.94 \\
\hline Finland & 0.61 & 0.68 & 0.90 & 0.78 & 0.84 & 0.93 \\
\hline Netherlands & 0.61 & 0.64 & 0.94 & 0.84 & 0.89 & 0.94 \\
\hline Norway & 0.74 & 0.80 & 0.92 & 0.91 & 0.94 & 0.97 \\
\hline Austria & 0.67 & 0.76 & 0.89 & 0.79 & 0.81 & 0.98 \\
\hline Switzerland & 0.86 & 0.90 & 0.96 & 0.92 & 0.97 & 0.95 \\
\hline Sweden & 0.70 & 0.76 & 0.91 & 0.89 & 0.91 & 0.97 \\
\hline Greece & 0.63 & 0.58 & 0.10 & 0.87 & 0.89 & 0.98 \\
\hline Ireland & 0.37 & 0.39 & 0.95 & 0.85 & 0.84 & 1.02 \\
\hline Portugal & 0.54 & 0.64 & 0.84 & 0.64 & 0.72 & 0.89 \\
\hline Spain & 0.29 & 0.51 & 0.57 & 0.59 & 0.79 & 0.74 \\
\hline Turkey & 0.36 & 0.43 & 0.83 & 0.64 & 0.76 & 0.84 \\
\hline Mean (unweighted) & 0.60 & 0.66 & 0.91 & 0.81 & 0.86 & 0.95 \\
\hline
\end{tabular}

Source: Dalum, Laursen and Willumsen (1996).

ARE CENTRAL AMERICAN EXPORT SPECIALIZATION PATTERNS "STICKY"? • KLAUS LINDEGAARD AND LEINER VARGAS 
significantly below unity at the $1 \%$ level for all 20 countries, meaning that the hypothesis of reverse or random patterns can be rejected. Since the $\beta$ values are significantly smaller than one, the elements of stickiness and incremental change are combined. Trade patterns do not change "overnight" and do not change fundamentally even over three decades (Dalum, Laursen and Willumsen, 1996, p.15).

\section{IV}

\section{Central American competitiveness studies}

Among others aspects of national systems of innovation, the trade specialization pattern is an important point of reference if any particular economy's scope for increasing competitiveness is to be gauged. A country's specialization patterns show its revealed comparative advantage, which is closely related to factor endowment and prices on the one hand and institutional and organizational conditions on the other.

Latin American research on trade and international competitiveness has mainly focused on the role of factor endowments (Fichet, 1991; Buitelaar and Fuentes, 1991; Fajnzylber, 1991), but recently the role of national innovation systems in competitiveness has been taken up and related to the technological specialization of the Latin American countries (Alcorta and Peres, 1996).

In relation to the Central American countries, a survey of the research dealing with the relationship between trade specialization patterns and competitiveness was carried out as part of the first phase of the SUDESCA project. ${ }^{5}$ According to this study (Gitli and Vargas, 1996), the research has so far concentrated on three aspects:

i) analysis of external factors affecting business decisions. So far the main concern has not been competitiveness itself but rather the global factors that might be related to it;

ii) studies based on the CAN computer program. ${ }^{6}$ In general, these studies have found evidence for a

\footnotetext{
${ }^{5}$ SUDESCA: Sustainable Development Strategies for Central America. Joint research project between the International Centre of Economic Policy for Sustainable Development (CINPE) of the National University of Costa Rica, and IKE and the Centre for Environment and Development of Aalborg University, Denmark, in collaboration with the University of El Salvador, the Fundación Nacional para el Desarrollo (FUNDE) of El Salvador and the Escuela de Economía Agrícola (ESECA) of the Autonomous University of Nicaragua.

${ }^{6}$ CAN: Competitive Analysis of Nations database, organized by ECLAC, that contains disaggregated information on OECD imports from the rest of the world between 1977 and 1994. See appendix A for further details.
}

dynamic of change in the trade specialization patterns of the Central American countries that tends to strengthen their comparative advantages. They generally depict the region as uncompetitive and its specialization pattern as being based on lowlevel competitive advantages, i.e., advantages deriving from cost factors such as cheap labour and the use of raw materials and natural resources;

iii) studies based on the Porter competitive advantage and clusters perspective. In general, these studies represent an important advance in the typification of the endogenous and exogenous factors affecting competitiveness in the subregion. The limitations of the main study carried out along these lines are due to the small number of sectors analysed and the limited statistical value of samples at the country level.

More specific studies relating to Latin American trade patterns have also been carried out in recent years by ECLAC, particularly in the joint ECLAC-UNIDO unit. Some of the results show very particular patterns. For example, a recent study based on the CAN database concluded that the situation of smaller countries in the region, those of Central America and the Caribbean, differed in several ways from that of the larger countries. An examination of their 10 principal exports, which account for $64 \%$ of the total, starkly demonstrates their new specializations: clothing and apparel. It is of significance to note that the new specializations of these smaller countries centre upon what might be considered less modern and less technologically sophisticated manufactures, the assembly of which is often carried out in export processing zones (Mortimore, 1995, p. 31).

Regarding the impact of the export model and specialization patterns on economic growth and local linkages, the author argues that in Latin America, even the three focal points of new international competitiveness in the region, that is Mexico (the

ARE CENTRAL AMERICAN EXPORT SPECIALIZATION PATTERNS "STICKY"? • KLAUS LINDEGAARD AND LEINER VARGAS 


\begin{tabular}{lll}
\hline & & All industrial sectors ${ }^{\mathrm{a}}$ \\
\hline Internal factors & External factors & Policy factors \\
\hline Strategic management & Monitoring of competitors & Clear rules and regulations \\
Financial management & Customs services & Educational investments \\
External logistics & Electrical energy & Health and social security \\
After-sales services & Technological research and management & Fair competition \\
& Credit availability & Regional agreements \\
\hline
\end{tabular}

Source: FEDEPRICAP/IDB (1994).

a Includes the food preservation industry (fruit and vegetables), apparel industry, paper products industry (packaging), agricultural machinery industry (coffee) and building industry (metal construction branch).

automotive industry, assembled goods), the Dominican Republic (goods assembled in the export processing zones) and Costa Rica (clothing and apparel, mostly assembled in free zones or using the temporary admission regime), share certain characteristics. They are industries in which higher levels of exports have been combined with low or lower levels of national value added in respect of physical inputs. Furthermore, they are industries very much dominated by foreign companies (Mortimore, 1995, p.51)

A prime example of research based on the Porter perspective is the comparative study of competitiveness in the manufacturing sectors of the subregion undertaken in the period from 1 November 1992 to 15 March 1994 by the Federation of Private Entities of Central America and Panama, in cooperation with the Inter-American Development Bank (FEDEPRICAP/IDB). This study considers the factors influencing competitiveness in individual companies, both external and internal. External factors are divided into four sets of business environment factors along the lines of the Porter "diamond" (Porter, 1991) and a set of government policy factors. The internal factors are structured along the lines of the Porter value chain model of the firm. The data were obtained through interviews, covering a total of 91 variables, which were conducted among 281 companies and organizations with the assistance of 31 expert panels throughout the subregion.

The competitive situation of all the Central American industries considered in the study is presented in table 2, where the critical factors are ranked by the importance ascribed to them in the responses.

The FEDEPRICAP/IDB study points to the important role of the environment within which each company operates, but it has some limitations that make it difficult to translate directly into the innovation systems analysis. The absence from the questionnaire of questions relating to internal research and development and innovation activities and to the external collaboration relationships of individual companies makes it impossible to attempt any systematic mapping of interactions linked to innovation, although these aspects were given some attention in the conclusions. What are focused on are information problems connected with the present business services infrastructure of the subregion, the weak sense of entrepreneurship and companies' inability to forge strategic alliances as a way of compensating for the poor services infrastructure.

Probably among the most complete and extensive studies into subregional competitiveness is the one recently published by the Central American Institute of Business Administration (INCAE, 1999). It attempts a detailed analysis of competitiveness in the Central American subregion using the Porter cluster methodology for several sectors. The result of this study is a group of specific cluster studies dealing with the apparel, electronics, agribusiness and tourist industries. In addition, a policy proposal entitled "Agenda for Competitiveness and Sustainable Development" was published and discussed with stakeholders.

The INCAE study has helped open up a debate about the need to develop a new kind of industrial policy in the subregion. The final report clearly recognizes the large differences among the countries and the need to put in place a basic framework of institutional and macroeconomic conditions. The weaknesses of the subregion as regards investment in education and infrastructure are also well diagnosed. The role of the private sector is emphasized, while trade negotiations and new environmental policies are also mentioned as

ARE CENTRAL AMERICAN EXPORT SPECIALIZATION PATTERNS "STICKY"? • KLAUS LINDEGAARD AND LEINER VARGAS 
a basic precondition for competitiveness. The study covers different areas, but there are some problems with the methodological framework it uses to select clusters with potential and with its choice of benchmarking scenarios for the subregion.

Taken all together, the competitiveness research carried out so far in the Central American subregion concerns problems related to short- and medium-term obstacles for export growth. There are practically no studies focusing on topics such as the characteristics, dynamism, strategic alliances and financing sources of exporters, or on national and regional innovation systems. It has also been found that there is a need to continue with research projects in the field of competitiveness in the subregion.

The results of the first phase of the SUDESCA project on systems of innovation in Central America have shown that there is strong potential for development and opportunities for learning and innovation through the existing production structure, the main requirement being to improve institutional and organizational conditions (Segura and Vargas, 1998; López and Amaya, 1998; Cummings and Mena, 1998). However, these studies also show that the existing production structure has created path dependency in sectors that have very few productive linkages with the rest of the economic system, possess few technological advantages and rely mainly on natural resources and low-skilled workers.

According to Segura and Vargas (1998), some of the most important problems with innovation policy in the case of Costa Rica are:

i) poor understanding of the innovation process;

ii) reproduction of an economy with low coherence and cohesion and little innovation potential because of a lack of linkages;

iii) risk of destruction of natural and social capital, which will reduce innovation capacity.

Costa Rica thus runs the risk of developing a dual economic structure with low long-run innovation capacity, as is reported to have occurred in the case of Mexico (Cimoli, 1999). Even though Costa Rica has been the most successful of the Central American countries in increasing exports and improving competitive performance, it still has many problems and is having to cope with a legacy of strong dependency from the past. In the other countries of the region, the conditions are worse and the results achieved, to judge by the dynamic of their participation in the export market, have been only moderate. The following section gives a very brief summary of the situation.

\section{The Central American export structure}

When Central American statistics are examined, some general considerations need to be taken into account. In the 1980s, the subregion was severely affected by the oil crisis and by political problems. Periods of civil war distorted economic development in El Salvador, Guatemala and especially Nicaragua. These need to be regarded as special situations, but more recent data could anticipate the path of post-conflict development, especially in Nicaragua (table 3 ).

As table 3 shows, the United States accounts for a very large share of exports from all the Central American countries; about $37 \%$ of the total in all years. The second largest market is Europe, with $26 \%$ of the total in 1995, followed by intraregional exports (23\%) and exports to other countries (14\%). In the period analysed, the European market increased in importance while the Central American economies became regionalized.
Table 4 shows export market shares by industry group, classified by product types (textiles, apparel, other manufactures and agriculture-based products). The reference market is that of the United States. We can see that agriculture (natural resource-based products) and apparel (low-skilled work) account for $86 \%$ of this trade, including maquila output going to the United States. We can also see that the apparel sector grew the fastest and showed strong dynamism in the early years of the 1990s.

As in other respects, Costa Rica and Guatemala are alike in that they specialize in agriculture and apparel. El Salvador specializes mainly in apparel while Nicaragua shows concentration in agricultural activities. Although the reference market is the United States, the pattern is very representative because this market takes about $50 \%$ of all Central American exports.

ARE CENTRAL AMERICAN EXPORT SPECIALIZATION PATTERNS "STICKY"? • KLAUS LINDEGAARD AND LEINER VARGAS 
TABLE 3

Central American export markets: Exports by region, 1990-1995

\begin{tabular}{|c|c|c|c|c|c|c|}
\hline Region & 1990 & 1991 & 1992 & 1993 & 1994 & 1995 \\
\hline \multicolumn{7}{|c|}{ A. Millions of dollars } \\
\hline Intraregional & 794.40 & 924.30 & 1156.86 & 1351.42 & 1499.90 & 1783.65 \\
\hline Europe & 1142.00 & 1073.80 & 1169.25 & 1212.38 & 1574.80 & 2033.32 \\
\hline United States & 1847.00 & 1897.80 & 2115.82 & 2394.23 & 2472.97 & 2866.99 \\
\hline Other countries & 959.40 & 942.60 & 821.28 & 870.33 & 886.83 & 1150.48 \\
\hline Total & 4742.80 & 4838.50 & 5263.20 & 5828.36 & 6434.51 & 7834.44 \\
\hline \multicolumn{7}{|c|}{ B. Percentages of the total } \\
\hline Intraregional & $16.75 \%$ & $19.10 \%$ & $21.98 \%$ & $23.19 \%$ & $23.31 \%$ & $22.77 \%$ \\
\hline Europe & $24.08 \%$ & $22.19 \%$ & $22.22 \%$ & $20.80 \%$ & $24.47 \%$ & $25.95 \%$ \\
\hline United States & $38.94 \%$ & $39.22 \%$ & $40.20 \%$ & $41.08 \%$ & $38.43 \%$ & $36.59 \%$ \\
\hline Other countries & $20.23 \%$ & $19.48 \%$ & $15.60 \%$ & $14.93 \%$ & $13.78 \%$ & $14.68 \%$ \\
\hline Total & $100.00 \%$ & $100.00 \%$ & $100.00 \%$ & $100.00 \%$ & $100.00 \%$ & $100.00 \%$ \\
\hline
\end{tabular}

Source: Prepared by the authors on the basis of Central American Monetary Council data (1996).

TABLE 4

Central America: Exports to and market share in the United States, by sector, 1990-1995

(Percentages of the total)

\begin{tabular}{|c|c|c|c|c|c|c|}
\hline \multirow[b]{2}{*}{ Sector } & \multicolumn{3}{|c|}{ Export share } & \multicolumn{3}{|c|}{ Market share } \\
\hline & 1990 & 1993 & 1995 & 1990 & 1993 & 1995 \\
\hline Textiles & 1.4 & 1.1 & 0.8 & 1.0 & 0.9 & 0.8 \\
\hline Apparel & 29.2 & 44.4 & 49.8 & 3.3 & 6.3 & 8.1 \\
\hline Other manufactures & 12.3 & 11.5 & 11.5 & 0.1 & 0.2 & 0.2 \\
\hline Industrial subtotal & 42.9 & 56.9 & 62.0 & 0.4 & 0.8 & 1.0 \\
\hline Agriculture & 54.9 & 41.2 & 36.1 & 6.7 & 7.9 & 8.1 \\
\hline Total & 100.0 & 100.0 & 100.0 & 0.9 & 1.3 & 1.4 \\
\hline
\end{tabular}

Source: Prepared by the authors on the basis of Fallas, Gitli and Vargas (1997) and data from the United States Department of Commerce/ ECLAC (1996).

\section{VI}

\section{RSCA test results for the Central American countries}

While specific product-by-product data are available for the trade relations between the Central American countries and the United States, we did not have access to data with the same structure for these countries' exports to OECD. To solve this specific data problem, we decided to use an OECD database (with data going up to 1994) specially managed by the CAN software developed by ECLAC. ${ }^{7}$ CAN uses a simple average of three years' trade as a reference for each year in order to standardize the data. We constructed different categories that were used to define product groups on the basis of the technical characteristics of the production process.

\footnotetext{
${ }^{7}$ See the ECLAC web site.
}

ARE CENTRAL AMERICAN EXPORT SPECIALIZATION PATTERNS "STICKY"? - KLAUS LINDEGAARD AND LEINER VARGAS 
We give figures for 1977-1994 in order to provide a medium-term perspective on trade patterns. ${ }^{8}$

Tables 5 and 6 show the results of the statistical test for the stability of national export specialization patterns in regression models, by country and for the subregion as a whole, in the short term (1979-1984, 1984-1988, 1988-1992) $)^{9}$ and in the medium term (1977-1994 and 1979-1992). ${ }^{10}$ Both tables show the

$\overline{8}$ The reader should be aware that changes in product quality and characteristics occur over the medium term, but the rigidities of the SITC classification mean that they go unperceived.

${ }^{9}$ Appendix A shows the revealed comparative advantage (RCA) and revealed symmetric comparative advantage (RSCA) ratios by sector: agriculture, energy, non-natural resource-based manufacturing, natural resource-based manufacturing, and others.

${ }^{10}$ We have been using 238 sectors in accordance with sitc, Revision 2. values of $\beta, \mathrm{R}$ and $\beta / \mathrm{R}$ in the different periods. In the following section of this paper, we use the data obtained to test the stability of Central American specialization patterns over the last 20 years.

The decomposition of the dispersion in a regression effect $(1-\beta)$ and a mobility effect (1-R) reveals that the $\beta$-values are significantly different from zero and significantly below unity at the $1 \%$ level for all five countries. As Dalum and Willumsen (1996) explain, trade patterns do not change overnight and do not change fundamentally even over two decades. This result points to a general tendency towards increase in industries that countries are highly specialized in. The $\beta$ specialization, which measures the ability of previous specialization patterns to determine those of the future, is strong, as indicated by the unweighted $\beta$ value of 0.87 (table 6 ).

TABLE 5

Central American countries: Stability and development of OECD export specialization patterns in three short-term periods ${ }^{a}$

(Revealed symmetric comparative advantage (RSCA) ratios)

\begin{tabular}{|c|c|c|c|c|c|c|}
\hline \multirow[t]{2}{*}{ Country } & \multicolumn{2}{|c|}{ 1979-1984 } & \multicolumn{2}{|c|}{ 1984-1988 } & \multicolumn{2}{|c|}{ 1988-1992 } \\
\hline & $\beta$ & $R$ & $\beta$ & $R$ & $\beta$ & $R$ \\
\hline Guatemala & 0.89 & 0.82 & 0.91 & 0.82 & 0.91 & 0.91 \\
\hline Honduras & 0.93 & 0.86 & 0.93 & 0.94 & 0.90 & 0.88 \\
\hline El Salvador & 0.75 & 0.78 & 0.78 & 0.74 & 0.89 & 0.76 \\
\hline Nicaragua & 0.76 & 0.81 & 0.72 & 0.75 & 0.88 & 0.73 \\
\hline Costa Rica & 0.95 & 0.80 & 0.86 & 0.88 & 0.99 & 0.90 \\
\hline Panama & 0.82 & 0.81 & 0.73 & 0.86 & 0.94 & 0.84 \\
\hline Central America & 0.95 & 0.90 & 0.90 & 0.92 & 0.99 & 0.93 \\
\hline
\end{tabular}

Source: Prepared by the authors on the basis of the CAN21 software and the SPSS set of social science statistics.

a All $\beta$ coefficients are statistically significant at $99 \%$.

TABLE 6

Central American countries: Stability and development of OECD export specialization in two medium-term periods ${ }^{a}$

(Revealed symmetric comparative advantage ( $R S C A)$ ratios)

\begin{tabular}{|c|c|c|c|c|c|c|}
\hline \multirow[t]{2}{*}{ Country } & \multicolumn{3}{|c|}{ 1979-1992 } & \multicolumn{3}{|c|}{ 1977-1994 } \\
\hline & $\beta$ & $R$ & $\beta / R$ & $\beta$ & $R$ & $\beta / R$ \\
\hline Guatemala & 0.81 & 0.68 & 1.20 & 0.77 & 0.61 & 1.25 \\
\hline Honduras & 0.77 & 0.65 & 1.18 & 0.79 & 0.68 & 1.15 \\
\hline El Salvador & 0.66 & 0.56 & 1.18 & 0.50 & 0.50 & 1.00 \\
\hline Nicaragua & 0.73 & 0.71 & 1.04 & 0.75 & 0.69 & 1.09 \\
\hline Costa Rica & 0.86 & 0.64 & 1.34 & 0.80 & 0.64 & 1.25 \\
\hline Panama & 0.77 & 0.72 & 1.06 & 0.72 & 0.66 & 1.09 \\
\hline Central America & 0.87 & 0.79 & 1.10 & 0.81 & 0.74 & 1.10 \\
\hline
\end{tabular}

Source: Prepared by the authors on the basis of the CAN21 software and the SPSS set of social science statistics.

${ }^{\text {a All }} \beta$ coefficients are statistically significant at $99 \%$.

ARE CENTRAL AMERICAN EXPORT SPECIALIZATION PATTERNS "STICKY"? - KLAUS LINDEGAARD AND LEINER VARGAS 
Concerning the short term (1979-1984, 1984-1988 and 1988-1992), it should be noted that the $\beta / \mathrm{R}$ ratio estimated $(1.05,0.98$ and 1.07) is indicative of a despecialization process Z. Only Nicaragua and El Salvador show a slower specialization process, something that is closely linked to the war periods in those countries during the 1970s and 1980s.

Care has to be taken in analysing the data, especially in the cases of Nicaragua and El Salvador, because the war periods fall between the periods analysed. Also, the OECD trade figures exclude the $25 \%$ or so of total trade flows that take place within the region and with other non-OECD countries.

In the medium-term periods (1977-1994 and 19791992), the results show a general increase in the dispersion of export specialization, implying a trend towards greater specialization. This increase in dispersion is substantial and can also be seen in the unweighted mean for $\beta / \mathrm{R}$, which is 1.10 . This tendency is particularly marked in the case of Costa Rica, where $\beta / \mathrm{R}$ is 1.34 in the period 1977-1994 and 1.25 in 1979-1992.

In conclusion, we have identified a process of specialization in the subregion during most of the period analysed. This was stronger in countries like Costa Rica which did not experience war or major political problems. Even in countries that experienced a war period in between, however, pattern stability and, more recently, an incipient specialization process have been detected.

According to these results, divergence has increased during the period analysed, if the comparison is with the divergence level identified by Dalum and Willumsen (1996). This is not a good omen for countries that are highly specialized in a few uncompetitive export products that can easily be displaced by competitors from other areas.

\section{VII \\ Path dependency and national systems of innovation from a developing country perspective}

The analysis of relative export specialization patterns sheds no light on any causal relationships or the initial specialization structure. Nor is it clear so far whether the small Central American countries are following a relative export specialization path similar to that of the less-developed OECD countries, or if they are closer to the development path of small (rich) OECD countries with a similar natural resource base.

The tension between convergent/divergent trade specialization processes on the one side and divergent technological specialization processes on the other, and the unclear relationship between these processes as a whole, are seen as the core of the dynamics of national systems of innovation analysis (Dalum and Willumsen, 1996, p. 1). These developments point to the interplay of international imitation processes and technology diffusion as a mechanism of convergence and institutional (contextual and historical) mechanisms of national divergence.

Path dependency of the trajectories and learning are central elements in the systems of innovation approach, whether the systems concerned are national or technological (Lindegaard, 1997). The present econometric study tends to confirm this, as do the OECD studies.

Just as the OECD market was examined for the export and specialization patterns analysis, intraindustry trade in Central America and other small market areas has to be considered. Trade among the Central American countries has grown fast in recent years, and this integration process could be a sign of a Central American innovation system emerging at the subregional level.

The inclusion of developing countries in the analysis of national innovation systems highlights the role of political factors, both internationally and nationally. Trade agreements and quota systems, in conjunction with national export promotion policies, are decisive factors in Central American exports to the OECD countries. This may go some way towards explaining the stability of trade patterns. The regulation of imports from developing countries will also to some extent determine the production structure of the OECD countries themselves, as we have indicated.

Stickiness, on the other hand, is a necessary component in all learning trajectories. New industrial

ARE CENTRAL AMERICAN EXPORT SPECIALIZATION PATTERNS "STICKY"? • KLAUS LINDEGAARD AND LEINER VARGAS 
policies, if based on a broader innovation strategy of "learning by doing", will seek out the competitive advantages created by new products, production processes, organizations and markets branching out from the existing structure. Here, institutional change can enhance interactive learning as well as existing skills, know-how and experience.

In this way, the current Central American innovation process of horizontal diversification within sectors may

APPENDIX A

Indicators and databases

Revealed comparative advantage (RCA) index

$$
R C A_{i j}=\frac{X_{i j} / \sum_{i} X_{i j}}{\sum_{j} X_{i j} / \sum_{i j} X_{i j}}
$$

where $X$ : exports of product $i$ from country $j$.

The index measures the share of national exports represented by exports of this product as compared to the share of all OECD country exports it represents (Dalum, 1992, p. 213).

Revealed symmetric comparative advantage (RSCA) indicator

$$
R S C A=(R C A-1) /(R C A+1)
$$

The indicator immunizes lack of normality in the distribution of the data (Dalum and Willumsen, 1996, p. 16).

Regression model

$$
R S C A_{i j}^{t 2}=\alpha_{i}+\beta_{i} R S C A_{i j}^{t 1}+\varepsilon_{i j}^{t 2}
$$

where $\mathrm{i}$ : country; $\mathrm{tl}$ : initial year; $\mathrm{t} 2$ : final year; $\alpha$ and $\beta$ : standard linear regression parameters; $\varepsilon$ : error term (Dalum and Willumsen, 1996, p. 7). translate into changes in the sectoral composition and export specialization of the countries' economies. There could be growth in manufacturing and high-technology products and services emerging out of the current (sticky) sectors of natural resource-intensive industries (agriculture) and apparel (textiles). The research challenge is to pursue closer investigation and understanding of these processes and of the opportunities for creating linkages and building networks for innovation and learning.

IKE trade database

This database belongs to the IKE (International Konkurrence Evne) group of the Department of Business Studies, Aalborg University, Denmark. Visible exports and imports are expressed in current dollars for the 23 OECD countries from 1961 onward. Data are delivered in the Standard International Trade Classification (SITC) format. ${ }^{11}$

CAN (Competitive Analysis of Nations) database ${ }^{12}$

The CAN computer software, developed by ECLAC, provides detailed knowledge of the competitive situation of 89 countries across almost 240 sectors during the period 1977-1994. It draws on an extensive database of foreign trade statistics (COMTRADE) to three digits of the SITC. The international market is defined in terms of the imports of OECD member countries, as these represent a demanding market for which reliable, consistent and up-to-date information is available. The CAN database is updated by ECLAC every two or three years, and the latest version, which is to be distributed shortly, will include data up to 1997.

\footnotetext{
${ }^{11}$ See OECD (1995).

12 See eClaC (1995).
} 
APPENDIX B

Central America: Revealed comparative advantage (RCA) and revealed symmetric comparative advantage (RSCA) ratios, by sector and country

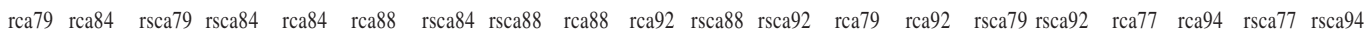

\begin{tabular}{|c|c|c|c|c|c|c|c|c|c|c|c|c|c|c|c|c|c|c|c|c|}
\hline \multicolumn{21}{|l|}{ By sector } \\
\hline Agriculture & 4.986 & 5.542 & 0.666 & 0.694 & 5.542 & 5.202 & 0.694 & 0.678 & 5.202 & 4.953 & 0.678 & 0.664 & 4.986 & 4.953 & 0.666 & 0.664 & 4.060 & 4.672 & 0.605 & 0.647 \\
\hline Energy & 0.344 & 0.355 & -0.488 & -0.476 & 0.355 & 0.253 & -0.476 & -0.596 & 0.253 & 0.145 & -0.596 & -0.747 & 0.344 & 0.145 & -0.488 & -0.747 & 0.533 & 0.077 & -0.305 & -0.856 \\
\hline \multicolumn{21}{|c|}{ Non-natural resource } \\
\hline manufactures & 0.421 & 0.726 & -0.407 & -0.159 & 0.726 & 0.578 & -0.159 & -0.267 & 0.578 & 0.425 & -0.267 & -0.404 & 0.421 & 0.425 & -0.407 & -0.404 & 0.485 & 0.388 & -0.347 & -0.441 \\
\hline \multicolumn{21}{|c|}{ Natural resource } \\
\hline manufactures & 0.178 & 0.220 & -0.698 & -0.640 & 0.220 & 0.376 & -0.640 & -0.453 & 0.376 & 0.493 & -0.453 & -0.340 & 0.178 & 0.493 & -0.698 & -0.340 & 0.226 & 0.555 & -0.631 & -0.286 \\
\hline Others & 1.727 & 1.169 & 0.267 & 0.078 & 1.169 & 0.803 & 0.078 & -0.109 & 0.803 & 0.767 & -0.109 & -0.132 & 1.727 & 0.767 & 0.267 & -0.132 & 1.262 & 0.556 & 0.116 & -0.285 \\
\hline \multicolumn{21}{|c|}{ By sector and country } \\
\hline \multicolumn{21}{|l|}{ Agriculture } \\
\hline Costa Rica & 5.989 & 6.185 & 0.714 & 0.722 & 6.185 & 5.498 & 0.722 & 0.692 & 5.498 & 5.070 & 0.692 & 0.671 & 5.989 & 5.070 & 0.714 & 0.671 & 5.178 & 4.833 & 0.676 & 0.657 \\
\hline El Salvador & 4.878 & 5.807 & 0.660 & 0.706 & 5.807 & 6.088 & 0.706 & 0.718 & 6.088 & 4.293 & 0.718 & 0.622 & 4.878 & 4.293 & 0.660 & 0.622 & 3.471 & 3.610 & 0.553 & 0.566 \\
\hline Guatemala & 5.087 & 6.150 & 0.671 & 0.720 & 6.150 & 6.198 & 0.720 & 0.722 & 6.198 & 4.961 & 0.722 & 0.664 & 5.087 & 4.961 & 0.671 & 0.664 & 4.282 & 4.741 & 0.621 & 0.652 \\
\hline Honduras & 5.713 & 6.530 & 0.702 & 0.734 & 6.530 & 6.652 & 0.734 & 0.739 & 6.652 & 5.048 & 0.739 & 0.669 & 5.713 & 5.048 & 0.702 & 0.669 & 5.142 & 4.261 & 0.674 & 0.620 \\
\hline Nicaragua & 5.202 & 4.764 & 0.678 & 0.653 & 4.764 & 5.480 & 0.653 & 0.691 & 5.480 & 5.420 & 0.691 & 0.688 & 5.202 & 5.420 & 0.678 & 0.688 & 3.720 & 6.393 & 0.576 & 0.729 \\
\hline Panama & 3.268 & 3.929 & 0.531 & 0.594 & 3.929 & 3.167 & 0.594 & 0.520 & 3.167 & 4.837 & 0.520 & 0.657 & 3.268 & 4.837 & 0.531 & 0.657 & 2.648 & 5.112 & 0.452 & 0.673 \\
\hline \multicolumn{21}{|l|}{ Energy } \\
\hline Costa Rica & 0.019 & 0.020 & -0.963 & -0.961 & 0.020 & 0.018 & -0.961 & -0.964 & 0.018 & 0.010 & -0.964 & -0.980 & 0.019 & 0.010 & -0.963 & -0.980 & 0.040 & 0.011 & -0.923 & -0.978 \\
\hline El Salvador & 0.294 & 0.202 & -0.545 & -0.664 & 0.202 & 0.144 & -0.664 & -0.748 & 0.144 & 0.007 & -0.748 & -0.986 & 0.294 & 0.007 & -0.545 & -0.986 & 0.676 & 0.007 & -0.194 & -0.987 \\
\hline Guatemala & 0.715 & 0.510 & -0.166 & -0.324 & 0.510 & 0.370 & -0.324 & -0.460 & 0.370 & 0.151 & -0.460 & -0.738 & 0.715 & 0.151 & -0.166 & -0.738 & 0.885 & 0.132 & -0.061 & -0.767 \\
\hline Honduras & 0.260 & 0.259 & -0.587 & -0.589 & 0.259 & 0.217 & -0.589 & -0.644 & 0.217 & 0.166 & -0.644 & -0.715 & 0.260 & 0.166 & -0.587 & -0.715 & 0.277 & 0.084 & -0.566 & -0.845 \\
\hline Nicaragua & 0.498 & 1.311 & -0.335 & 0.135 & 1.311 & 1.667 & 0.135 & 0.250 & 1.667 & 1.451 & 0.250 & 0.184 & 0.498 & 1.451 & -0.335 & 0.184 & 1.017 & 0.128 & 0.008 & -0.773 \\
\hline Panama & 0.263 & 0.407 & -0.584 & -0.422 & 0.407 & 0.266 & -0.422 & -0.580 & 0.266 & 0.145 & -0.580 & -0.746 & 0.263 & 0.145 & -0.584 & -0.746 & 0.238 & 0.188 & -0.616 & -0.683 \\
\hline \multicolumn{21}{|l|}{ Non-natural } \\
\hline \multicolumn{21}{|c|}{ resource manufactures } \\
\hline Costa Rica & 0.148 & 0.191 & -0.742 & -0.679 & 0.191 & 0.187 & -0.679 & -0.685 & 0.187 & 0.243 & -0.685 & -0.610 & 0.148 & 0.243 & -0.742 & -0.610 & 0.145 & 0.245 & -0.747 & -0.607 \\
\hline El Salvador & 0.075 & 0.221 & -0.861 & -0.639 & 0.221 & 0.110 & -0.639 & -0.802 & 0.110 & 0.141 & -0.802 & -0.753 & 0.075 & 0.141 & -0.861 & -0.753 & 0.238 & 0.133 & -0.615 & -0.765 \\
\hline Guatemala & 0.041 & 0.400 & -0.922 & -0.429 & 0.400 & 0.111 & -0.429 & -0.800 & 0.111 & 0.102 & -0.800 & -0.815 & 0.041 & 0.102 & -0.922 & -0.815 & 0.056 & 0.102 & -0.894 & -0.815 \\
\hline Honduras & 0.394 & 0.287 & -0.434 & -0.553 & 0.287 & 0.324 & -0.553 & -0.511 & 0.324 & 0.327 & -0.511 & -0.507 & 0.394 & 0.327 & -0.434 & -0.507 & 0.182 & 0.360 & -0.692 & -0.471 \\
\hline Nicaragua & 0.120 & 0.024 & -0.785 & -0.953 & 0.024 & 0.010 & -0.953 & -0.981 & 0.010 & 0.085 & -0.981 & -0.844 & 0.120 & 0.085 & -0.785 & -0.844 & 0.206 & 0.050 & -0.658 & -0.904 \\
\hline Panama & 1.662 & 2.264 & 0.249 & 0.387 & 2.264 & 1.594 & 0.387 & 0.229 & 1.594 & 1.483 & 0.229 & 0.194 & 1.662 & 1.483 & 0.249 & 0.194 & 2.091 & 1.515 & 0.353 & 0.205 \\
\hline \multicolumn{21}{|c|}{$\begin{array}{l}\text { Natural resource } \\
\text { manufactures }\end{array}$} \\
\hline Costa Rica & 0.129 & 0.286 & -0.772 & -0.555 & 0.286 & 0.405 & -0.555 & -0.423 & 0.405 & 0.521 & -0.423 & -0.315 & 0.129 & 0.521 & -0.772 & -0.315 & 0.166 & 0.552 & -0.716 & -0.288 \\
\hline El Salvador & 0.331 & 0.307 & -0.502 & -0.531 & 0.307 & 0.286 & -0.531 & -0.555 & 0.286 & 0.668 & -0.555 & -0.199 & 0.331 & 0.668 & -0.502 & -0.199 & 0.411 & 0.781 & -0.418 & -0.123 \\
\hline Guatemala & 0.037 & 0.064 & -0.928 & -0.880 & 0.064 & 0.217 & -0.880 & -0.643 & 0.217 & 0.528 & -0.643 & -0.309 & 0.037 & 0.528 & -0.928 & -0.309 & 0.029 & 0.564 & -0.943 & -0.279 \\
\hline Honduras & 0.050 & 0.101 & -0.905 & -0.817 & 0.101 & 0.142 & -0.817 & -0.752 & 0.142 & 0.501 & -0.752 & -0.333 & 0.050 & 0.501 & -0.905 & -0.333 & 0.039 & 0.643 & -0.925 & -0.217 \\
\hline Nicaragua & 0.082 & 0.010 & -0.849 & -0.980 & 0.010 & 0.034 & -0.980 & -0.935 & 0.034 & 0.160 & -0.935 & -0.723 & 0.082 & 0.160 & -0.849 & -0.723 & 0.123 & 0.213 & -0.780 & -0.649 \\
\hline Panama & 0.396 & 0.365 & -0.432 & -0.465 & 0.365 & 0.656 & -0.465 & -0.207 & 0.656 & 0.379 & -0.207 & -0.451 & 0.396 & 0.379 & -0.432 & -0.451 & 0.594 & 0.336 & -0.254 & -0.497 \\
\hline \multicolumn{21}{|l|}{ Others } \\
\hline Costa Rica & 0.298 & 0.566 & -0.541 & -0.277 & 0.566 & 0.522 & -0.277 & -0.314 & 0.522 & 0.403 & -0.314 & -0.426 & 0.298 & 0.403 & -0.541 & -0.426 & 0.142 & 0.406 & -0.752 & -0.422 \\
\hline El Salvador & 0.234 & 0.209 & -0.620 & -0.654 & 0.209 & 0.184 & -0.654 & -0.689 & 0.184 & 0.335 & -0.689 & -0.498 & 0.234 & 0.335 & -0.620 & -0.498 & 0.280 & 0.285 & -0.562 & -0.557 \\
\hline Guatemala & 0.435 & 0.408 & -0.394 & -0.420 & 0.408 & 0.339 & -0.420 & -0.494 & 0.339 & 0.352 & -0.494 & -0.480 & 0.435 & 0.352 & -0.394 & -0.480 & 0.485 & 0.304 & -0.347 & -0.533 \\
\hline Honduras & 0.393 & 0.258 & -0.436 & -0.590 & 0.258 & 0.350 & -0.590 & -0.482 & 0.350 & 0.195 & -0.482 & -0.673 & 0.393 & 0.195 & -0.436 & -0.673 & 0.455 & 0.183 & -0.374 & -0.691 \\
\hline Nicaragua & 1.226 & 1.898 & 0.102 & 0.310 & 1.898 & 2.823 & 0.310 & 0.477 & 2.823 & 2.158 & 0.477 & 0.367 & 1.226 & 2.158 & 0.102 & 0.367 & 1.069 & 1.887 & 0.033 & 0.307 \\
\hline Panama & 7.531 & 3.274 & 0.766 & 0.532 & 3.274 & 1.526 & 0.532 & 0.208 & 1.526 & 2.444 & 0.208 & 0.419 & 7.531 & 2.444 & 0.766 & 0.419 & 5.148 & 1.739 & 0.675 & 0.270 \\
\hline
\end{tabular}

Source: Prepared by the authors on the basis of data from CAN21 and Vargas (1999).

ARE CENTRAL AMERICAN EXPORT SPECIALIZATION PATTERNS "STICKY"? • KLAUS LINDEGAARD AND LEINER VARGAS 


\section{Bibliography}

Alcorta, L. and W. Peres (1996), Sistemas de innovación y especialización tecnológica en América Latina y el Caribe, Desarrollo productivo series, No. 33, LC/G.1913, Santiago, Chile, ECLAC.

Buitelaar, R. and J. Fuentes (1991): The competitiveness of the small economies of the region, CEPAL Review, No. 43, LC/G.1654-P, Santiago, Chile, April.

Central American Monetary Council (1996): Boletín estadístico, 1995, San Jose, Costa Rica.

Cimoli, Mario (1999): The Mexican innovation system: Stylized facts and evolutionary patterns, document presented at the International Seminar on Innovation, Competitiveness and Environment in Central America: A System of Innovation Approach, February.

Cummings, A. and R. Mena (1998): Policies from the perspective of innovation. The case of El Salvador, SUDESCA Research Paper, No. 28, Heredia, Aalborg University/International Centre of Economic Policy for Sustainable Development (CINPE).

Dalum, B. (1992): Export specialization, structural competitiveness and national systems of innovation, in B.-A. Lundvall (comp.), National systems of innovation. Towards a theory of innovation and interactive learning, London, Pinter Publishers.

Dalum, B. and G. Willumsen (1996): Are OECD export specialization patterns "sticky"? Relations to the convergence-divergence debate, DRUID Working Paper, No. 96-3, Aalborg, Aalborg University.

Dalum, B., K. Laursen and G. Willumsen (1996): The long term development of OECD export specialization patterns: Despecialization and "stickiness", DRUID Working Paper, No. 9614, Aalborg, Aalborg University.

Dosi, G. (1982): Technological paradigms and technological trajectories: A suggested interpretation of the determinants and direction of technical change, Research Policy, vol. 11, No. 3.

Dosi, G., K. Pavitt and L. Soete (1990): The economics of technical change and international trade, Exeter, Harvester Wheatsheaf.

ECLAC (Economic Commission for Latin America and the Caribbean) (1995): CAN: Competitive Analysis of Nations: software to evaluate and describe the international competitive environment, version 2.0, user's manual, LC/G.1863, Santiago, Chile, joint ECLAC/UNIDO unit.

Edquist, C. (ed.) (1997): Systems of innovation: technologies, institutions and organizations, London, Pinter Publishers.

Fallas, H., E. Gitli and L. Vargas (1997): Análisis que sustenta el otorgarmiento de preferencias arancelarias especiales al sector industrial de Centroamérica por parte de la Unión Europea, Heredia, Federation of Chambers and Associations of Exporters of Central America and the Caribbean/ International Centre of Economic Policy for Sustainable Development (FECAEXCA/CINPE), National University of Costa Rica.
Fajnzylber, F. (1991): International insertion and institutional renewal, CEPAL Review, No. 44, LC/G.1667-P, Santiago, Chile, August.

FEDEPRICAP/IDB (Federation of Private Entities of Central America and Panama/Inter-American Development Bank) (1994): Estudio de competitividad de Centroamérica y Panamá. Informe final, H. Fallas (coord.), San Jose, Costa Rica.

Fichet, G. (1991): The competitiveness of Latin American industry, CEPAL Review, No. 43, LC/G.1654-P, Santiago, Chile, April.

Freeman, C. (1992): The economics of hope, London, Pinter Publishers.

Gitli, E. and L. Vargas (1996): State-of-the-art research on competitiveness in Central America. Costa Rica, SUDESCA Reports series, No. 3, Heredia, Aalborg University/National University of Costa Rica.

INCAE (Instituto Centroamericano de Administración de Empresas) (1999): Centroamérica en el siglo XXI: Una agenda para la competitividad y el desarrollo sostenible. Documento final, Alajuela, Costa Rica, unpublished, July.

Lindegaard, K. (1997): Estado del arte del análisis de sistemas de innovación, sUDESCA Research Paper, No. 7, Heredia, Aalborg University/International Centre of Economic Policy for Sustainable Development (CINPE).

López, M. and L. Amaya (1998): Análisis de políticas desde la perspectiva de innovación: el caso de Nicaragua, SUDESCA Research Paper, No. 27, Heredia, Aalborg University/ International Centre of Economic Policy for Sustainable Development (CINPE).

Lundvall, B.-A. (comp.) (1992): National systems of innovation: Towards a theory of innovation and interactive learning, London, Pinter Publishers.

Lundvall, B.-A. and B. Johnson (1994): The learning economy, Journal of Industry Studies, vol. 1, No. 2, London, Sage.

Mortimore, Michael (1995): Paths towards international competitiveness: A CANanalysis, Desarrollo productivo series, No. 25, LC/G.1869, Santiago, Chile, ECLAC.

OECD (Organisation for Economic Co-operation and Development) (1995): Trade by Commodities, Series C. Exports and imports of "visible" goods in current $\$$ to 23 OECD countries from 1961 onwards, OECD Statistical Series, Brussels.

Porter, M. (1991): The Competitive advantage of nations, New York, The Free Press.

Segura, O. and L. Vargas (1998): Policy learning and innovation in Costa Rica, SUdesca Research Paper, No. 25, Heredia, Aalborg University/International Centre of Economic Policy for Sustainable Development (CINPE).

United States Department of Commerce/Economic Commission for Latin America and the Caribbean (ECLAC) (1996): Magic users manual, version 1.0, Mexico City.

Vargas, L. (1999): Central American export specialisation: Data report, Heredia, Aalborg University/International Centre of Economic Policy for Sustainable Development (CINPE). 